\title{
The role of the theology of retribution in the growth of Pentecostal-Charismatic churches in Africa
}

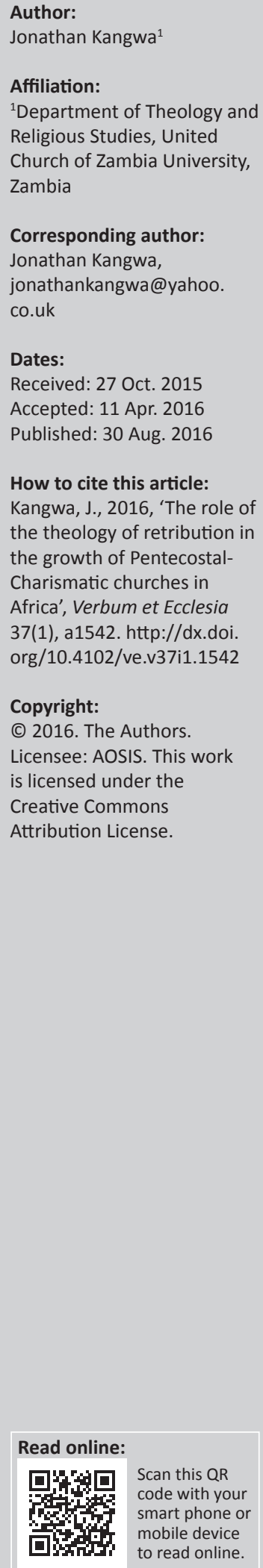

This article considers the contribution of the theology of retribution to the growth of Pentecostal-charismatic churches in Africa. It argues that the beliefs and practices of African Pentecostal-charismatic churches uphold the theology of retribution. The success of prophecy and healing in these churches is based on their extensive engagement with the theology of retribution. To show this, the article begins with a brief review of the principle of retribution, describing it as resulting from the conception of a perfect and just universe in which every human deed brings with it consequences. Good deeds are followed by good consequences, evil deeds have bad consequences. Based on this understanding of retribution, the article discusses beliefs and practices of Pentecostal-charismatic churches which support the principle of retribution and whose involvement in healing and prophecy is attractive to Africans. The article concludes that the current discourse on Pentecostal-charismatic churches in Africa focuses strongly on the aspects of healing and prophecy while neglecting the contribution made by the theology of retribution to the popularity of these churches.

Intradisciplinary and/or interdisciplinary implications: Located within African theologies and African church history, this article maintains that the current discourse on Pentecostal and charismatic churches in Africa, as it concentrates on healing and prophecy, overlooks the role played by the theology of retribution in the growth of these churches.

\section{Introduction}

The growth of world Christianity and of Christianity in Africa is well documented (Amanze 2013; Barrett, Kurian \& Johnson 2001; Gifford 1991; Jenkins 2007; Johnson and Ross 2009; Robert 2009; Sanneh 1990, 2008; Schreiter 2004, 1991; Togarasei 2015; Walls 2002; Kalu 2002). The centre of gravity of world Christianity is shifting to Asia and, southwards, to Africa and Latin America. In Africa, south of the Sahara, there has been a proliferation of Pentecostal-charismatic churches, most of which share common features (Amanze 2013:1; Togarasei 2015:57). Many of these churches also show some features of the spirituality exhibited in African traditional religions (Kalu 2008:186). ${ }^{1}$ The present article examines the role of the theology of retribution in the unprecedented growth of Pentecostal-charismatic churches in Africa.

The article draws on information obtained from the messages preached by prophets and pastors in Pentecostal-charismatic churches during their Sunday services. It also makes use of information posted on various church websites, while the author has observed miracle services broadcast live on various TV stations owned by African Pentecostal-charismatic churches. The article is furthermore based on a review of relevant recent ecumenical, Pentecostal, and African theological literature. It sets out by analysing the growth of Christianity in Africa and the theology of retribution. It then considers how the theology of retribution informs the beliefs and practices of African Pentecostal-charismatic churches. The basic argument put forward is that the growth of Pentecostal-charismatic churches in Africa is the result of their success in articulating and applying the theology of retribution in healing and prophecies. The retribution ${ }^{2}$ concept is pervasive in Pentecostal-charismatic churches that attract a large following of Africans who are in search of personal, spiritual and economic help.

\section{World Christianity and its shifting centre of gravity}

World Christianity has grown considerably in the past century, and more specifically in the last three decades. Since 1915 more than 500 million people have converted to Christianity, with 80\%

1.Pentecostal-charismatic churches in Africa manifest some of the practices of healing and prophecies found in African traditional religions, but must be distinguished from these (Anderson 2001; Hazra 2003:26).

2.The health and welfare theology emphasised by the prosperity gospel holds that those who follow God's commandments and are committed to tithing will prosper while those who disobey must expect to face calamities on earth (cf. Gifford 1991, 1998). 
of these becoming Christians after 1970 (Adedibu 2015:39). Samarin (cited in Togarasei 2015:57), reasoning from a sociological point of view, predicted in 1966 that Africa would become secular in the next decades. However, in the 1970s already, there were indications that the centre of gravity of Christianity was shifting from the northern to the southern hemisphere (Robert 2000). Current statistics show that most of the growth of Christianity has taken place in the global south (Adedibu 2015; Amanze 2013; Jenkins 2007:2-3; Robert 2009; Sanneh 2008:xx). This tendency has been referred to as 'a shift in Christianity's centre of gravity' (Togarasei 2015:56). Adedibu (2015) notes:

The shift of the centre of gravity of Christianity to the majority of the world [global south] has overlapped with the global rise of Pentecostalism characterised by its emphasis on mission. Pentecostal and charismatic movements, in all their 'multifaceted variety, probably constitute the fastest growing churches within Christianity today'. Barrett and Johnson note that if present trends continue, by 2025 69\% of the world's Christians will live in the global south, with only $31 \%$ in the global north. (p. 40)

The rapid growth of Christianity in the southern hemisphere has offset ${ }^{3}$ the decline of Christianity in its traditional strongholds, particularly Europe (Amanze 2013; Jenkins 2007:2-3; Robert 2009; Sanneh 2008:xx; Togarasei 2015:56). Today only one in four Christians live in Europe, 37\% live in America, 24\% in sub-Saharan Africa and the Asia-Pacific region accounts for $13 \%$. In Africa south of the Sahara much of the growth of Christianity occurred, not in mission churches, but in Pentecostal-charismatic churches (Amanze 2013:2).

The demographic shift has brought about a diversity of forms of Christianity in Africa. The diversity has evolved over time, beginning with the African initiated churches and, more recently, with many different versions of Pentecostalcharismatic faiths (Togarasei 2015). This leads Jenkins $(2007: 3,90)$ to conclude that by 2050 the largest Christian population will be residing in Africa which is already today the continent with the fastest growing Christian churches in the world. Pentecostal-charismatic churches in Africa are popular because they embrace the performance of miracles that satisfy the economic and social needs of people. The prophets in these churches predict the future and promise members good fortune in the present world rather than in the hereafter (Amanze 2013:2; Togarasei 2015:60). Inherent in prophecies and healing miracles is the theology of retribution.

\section{Principle of retribution}

Retribution is defined by the Macmillan English Dictionary for Advanced Learners (Mayor et al. 2002:369) as 'punishment that someone deserves because they have done something very bad'. Divine retribution is defined as 'punishment from God'. In other words, the principle of retribution holds that, in this

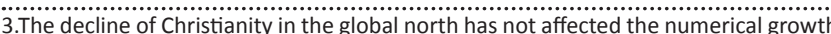
of Christianity globally, of Christianity globally Furthermore, Africa is now a major source of missionaries who are sent out into the world at large. For example, in Britain Christianity is being transformed by the emergence and continued growth of African-led Pentecostal-charismatic churches (Adedibu 2015:39). world, good people are blessed while the wicked are punished (cf. Menezes 2013:37). In trying to provide a system of wise maxims that are conducive to a happy life, the principle emphasises that God has created the world with a built-in principle whereby the wise and good are rewarded whereas the fools and the wicked get punished. It is up to men and women to make wise choices and avoid negative consequences. Those who want to succeed in life cope with its ups and downs and avoid the dangers that may lead to disaster (Menezes 2013:37; Wittenberg 1994:62 cf. Pr 6:20).

The background of the theology of retribution is formed by the conception of a perfect and just universe in which every human deed has its consequences. Good deeds have good consequences and evil deeds lead to bad consequences (Wittenberg 1994:62). He or she who obeys God's will and lives a just and righteous life will be blessed with prosperity, fecundity, a large family, happiness, promotion at work, and good health. On the other hand, the wicked person who does not believe in Jesus and transgresses God's commandments will encounter misfortune, illness and all sorts of failure in life. One reaps what one plants. Planting the seed of righteousness will automatically lead to success whereas a bad seed (wickedness) results in a harvest of failure and disaster (Wittenberg 1994:62, Dt 28, Pr 11:30, 14:22, 22:8, Job 15:35).

The development of the theology of retribution can be traced in the Old Testament (OT). As Forti (2014:142) observes, the 'action-consequence paradigm' is enshrined in the laws of retribution found in the book of Deuteronomy. According to these laws divine will and human action determines the events in one's life. Deuteronomy portrays a 'theocentric, covenantal and religio-moralistic paradigm', imposed on the Israelites by Yahweh (Forti 2014:142). ${ }^{4}$ Thus Deuteronomy 4:1-6 states:

And now, o Israel, listen to the statutes and the rules that I am teaching you, and do them, that you may live, and go in and take possession of the land that the Lord, the God of your fathers, is giving you. You shall not add to the word that I command you, nor take from it, that you may keep the commandments of the Lord your God that I command you. Your eyes have seen what the Lord did at Baal-Peor, for the Lord your God destroyed from among you all the men who followed the Baal of Peor. But you who held fast to the Lord your God are all alive today. See, I have taught you statutes and rules, as the Lord my God commanded me that you should do them in the Land that you are entering to take possession of it. ${ }^{5}$

The concept of retribution is central to the ethical guidelines given to the Israelites under the Mosaic covenant on Mount Sinai: Obedience to the law attracts blessings and neglect brings curses (Dt 28). McConville (1994:199) identifies some

4.Deuteronomy 18:15-22 redefines prophecy to differentiate it from 'detestable divination that would bring curses upon the Israelites. The redefinition of prophecy divination that would bring curses upon the Israelites. The redefinition of prophecy concludes the collection of Torah in Deuteronomy 16:18-18:22 which served as a constitution for Israel. It is not clear whether this collection existed independently from the Deuteronomistic context. Nonetheless, the collection of Torah provided ethical guidelines for the Israelites. These guidelines reinforce the principle of
retribution (cf. Bosman 2014:380-390).

5.All bible quotations are taken from the English Standard Version. 
similarities between the book of Deuteronomy and political treaties made by Hittite kings with weaker states and the law codes found in the ancient Near East such as the Babylonian Hammurabi. ${ }^{6}$ The treaties emphasise the element of relationship and loyalty between the parties involved. Deuteronomy shows a similar pattern to that of the Hittite treaty, although the section on curses in Deuteronomy is longer (cf. Dt 30:19-20).

The principle of retribution was linked to the covenant relationship between God and the Israelites. The idea had been developed during the time of Abraham (Gn 15:18, 17:2) and at Sinai or Horeb the commandments were given as (ethical) guidelines. God's promises and the need for Israel to obey God's commands are elaborated (McConville 1994:200, Ex 19:5, 20:1-17). According to the theology of Deuteronomy, Israel is to worship Yahweh alone (Dt 6:4). Yahweh is presented as a God of nature and history who controls fertility and the seasons, thus preventing the Israelites from worshipping Baal, a Canaanite god of nature. Deuteronomy further stresses that there is a balance between loyalty and obedience to God's commandments on the one hand, and prosperity or material blessings on the other (McConville 1994:200; Dt 6:24-25). In keeping God's commandments, Israel would experience freedom, good harvests, fecundity, and be protected from possible exploitation by non-Israelites (Dt 30:19-20).?

The concept of keeping God's commandments so that one may gain prosperity has gradually taken on the rigidity of a dogma (Wittenberg 1994:63). Forti (2014:130) identifies two variant models of reward and punishment in the OT which developed over time. These is the 'pragmatic-utilitarian model' according to which recompense is embodied in the consequences of a person's deeds, and the 'divine retribution model' according to which God renders to human beings on the basis of their actions. The rhetoric of admonition and exhortation found in the OT is often used to appeal to the listeners' 'common sense on the basis of the concept of morality, employing an epistemology founded concomitantly on universal truths and on Israelite morality and law' (Forti 2014:130). Some of the teachings found in the OT (as well as in the New Testament) are set within a religious-moral framework founded upon the principle of divine retribution, while others reflect a pragmatic or utilitarian model, implying that the nature of an action determines its consequences (Forti 2014:131, Dt 28).

A comparison of 2 Kings 15:5 with 2 Chronicles 26:20ff. gives us a divine retribution model. King Azariah (Uzziah) of

6.A Hittite treaty had the following components: a preamble introducing the parties a historical prologue referring to previous relations between the parties, genera stipulations showing the nature of the future relationship between the parties, specific stipulations regarding the detailed requirements made of the weaker party witnesses who were normally gods called to witness the treaty and blessings and curses pronounced for loyalty and disloyalty respectively (McConville 1994:199). this vision was not realised. The book seems to be aware of the inability of the people to keep the covenant with God from the very beginning (cf. Dt 1:26-46). Further, chapter 30 points to people's inability to keep God's commandments, indicating that curses are likely to occur before a final salvation is possible (c McConville 1994:200).
Judah was struck by Yahweh with leprosy. The author of Chronicles concludes that the king must have committed a sin (verses 16-19). It is stated that Uzziah made an offering that he restricted to the priests and for which his leprosy is a form of punishment (Kutsch 1986:339, cited in Wittenberg 1994:63). Furthermore, wisdom literature provides us with the concept of retribution (both divine and pragmatic). In the book of Job is stated that his friends explained Job's suffering as a result of his sinning. Eliphaz says:

Remember: who that was innocent ever perished? Or where were the upright cut off? As I have seen, those who plough iniquity and sow trouble reap the same. By the breath of God they perish, and by the blast of his anger they are consumed. (Job 4:7-8)

Because Job's friends felt sure that his illness was caused by sin they counselled him to repent and to submit himself to God's judgment (Job 5:8, 17-26). Like modern prophets and prophetesses in African Pentecostal-charismatic churches, Job's friends are convinced that their doctrine is a valid explanation of Job's plight. But Job denies guilt (Job 6:24). He questions the validity of the principle of retribution:

Why do the wicked live on, reach old age, and grow mighty in power? Their offspring are established in their presence, and their descendants before their eyes. Their houses are safe from fear, and no rod of God is upon them... They spend their days in prosperity, and in peace they go down to Sheol. (Job 21:7-9, 13)

As Job's friends see it, the righteous person (saddiq) who meets the requirements of God's commandments will prosper while a wicked person will suffer (Menezes 2013:37). For them, in God's just order of creation, the person who obeys God's commandments will ultimately be blessed by God whereas any wealth gained by unjust means will soon vanish (Wittenberg 2007:77). ${ }^{8}$ While, in the context of the law of natural justice, this may appear to be logical reasoning, the theory becomes problematic when the opposite happens. Reality shows that bad things also happen to good people. There is no recognisable link between righteousness and prosperity. Many people suffer poverty and pain due to structural forces at play in society (Wittenberg 1994:63, 2007:77).

The age of the Maccabees seems to have had a notion of future divine retribution (Beecher 2015). Martyrdom, belief in resurrection and faith in eternal retribution pervaded the army of Judas Maccabeus. The belief in immortality and eternal retribution was apparent in the performance of heroic actions and courageously borne suffering. Many didactic statements of the Christian church in the first centuries of its existence embodied this belief. The church fathers during the patristic period interpreted the Bible allegorically and in a manner that emphasised future retribution. Punishments and blessings in the OT were regarded as types or symbols of spiritual punishments and blessings. Thus, natural disease

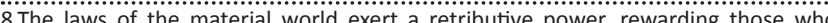
regard and obey, and punishing those who disobey them Retribution, also, has been believed to exist in the various systems of supernatural powers that by human been believed to exist in the various systems of supernatural powers that by human
beings in various periods have been accepted as valid. Under such systems, similarly, beings in various periods have been accepted as valid. Under such systems, similarly,
reward and punishment result from obedience and disobedience (Beecher 2015). 
and death were seen as symbols of spiritual disease and death (Beecher 2015).

The idea of future retribution has remained part of the beliefs and practices of the Christian church but the notion is extended to include a future life so that the idea of eternity is added. Eternal life or eternal fire is believed to await human beings after death. This perspective, propagated by mainline churches, spread intense fear among Christians (Beecher 2015). However, Pentecostal-charismatic churches in Africa no longer believe in future retribution. They believe in blessings and curses that affect the present life (Phiri 2008:96; Togarasei 2015). Phiri (2008) and Gifford (1998:181-231) show that Pentecostal-charismatic churches in African countries such as Zambia and Ghana believe in God's blessings in life here and now. ${ }^{9}$ Taking a closer look at the beliefs and practices of these churches we recognise the tenets of retribution theology that have been discussed above.

\section{Reasons for the growth of Pentecostal-charismatic churches}

A number of factors have contributed to the growth of those churches in Africa that adhere to a variety of forms of Pentecostalism. Attempts have been made to identify and describe these different forms that have changed the face of Christianity on the continent (Anderson 2004; Anderson et al. 2010; Kalu 2008; Lado 2006; Sanneh 1990). Lado (2006) identifies four main variants of African Pentecostalism, namely the independent African churches with Pentecostal features (also called spiritual churches), the classic Pentecostal churches (dependent or independent), the neoPentecostal churches, and the charismatic movements within the Roman Catholic or Protestant churches. There is a wide range of Christian views and practices that share characteristics and are associated with renewal movements. Generally, the different Pentecostal-charismatic churches have certain expressions in common, based on a shared concern that unites them, namely the emphasis on prophecy, the power of the Holy Spirit, the material prosperity of believers and healing miracles (Amanze 2013; Hazra 2003).

In this context a first point of importance is that the theology of Pentecostal-charismatic churches accords well with the spirituality of African initiated churches and African traditional religion (Amanze 2013; Kalu 2008). Kalu (2008:186) rightly observes that 'Pentecostalism has produced a culture of continuity by mining primal worldview, reproducing an identifiable character, and regaining a pneumatic and charismatic religiosity that existed in traditional African society'. African theologians have shown that many African worldviews consider life on earth in relation to religion and the spirit world (Pobee 1996:10). Rites of passage such as birth, puberty, marriage and death have a spiritual

9.This seems consistent with the theology of Deuteronomy that speaks of blessings and curses without any reference to the future If the nation was loyal and obedient, God promised that people would enjoy good health, a long life, frutful seasons, God promised that people would enjoy good health, a long life, fruitful seasons, military ascendency among the nations, national wealth, honour and power. If disobedient and idolatrous, God threatened that they would suffer famine, disease, defeat in war, captivity, poverty and shame (Beecher 2015; Dt 28, 31). significance. Events and phenomena such as infertility, drought, road accidents, etc., are explained as caused by purposive acts of spiritual forces, be they evil or benevolent. Underlying this view is the belief that humankind is vulnerable to spiritual forces. Consequently salvation is perceived as the freedom from spiritual powers that limit or hinder humans in their striving for well-being. In other words, in the African traditional religion salvation occurs in the here and now and brings physical and spiritual wellbeing (Mbiti 1974:112-113). African theologians have attributed the rapid growth of Christianity in Africa to the notion of Africans being inherently, or 'notoriously' as John Mbiti puts it, religious (Togarasei 2015:57).

Thus, the emphasis on material success found in Pentecostalcharismatic churches is due, not so much to secularism, but to the tenets of African religio-culture. Nyamiti (1987) observes that:

African religious behavior is centered mainly on man's life in this world, with the consequence that religion is chiefly functional, or a means to serve people to acquire earthly goods and to maintain social cohesion and order. (p. 60)

Indigenous Africans continue to adhere to certain basic elements of African traditional religion and culture.

African Pentecostal-charismatic churches have shown resilience in engaging with aspects of both globalisation and African worldviews. Amanze (2013) observes:

\footnotetext{
... the new Pentecostal-charismatic Churches have a good grasp of the African psyche whose main concern is to overcome the powers of evil, which are considered to be the source of all kinds of disease, poverty, misfortunes, bad luck, human suffering and ultimately death. Therefore, there appears to be an insatiable need among Africans to have the power that can enable them to manipulate both natural and supernatural powers in order to achieve their objectives in life. (p. 2)
}

Due to this need, many Africans are attracted to the performances of prophets and prophetesses in Pentecostalcharismatic churches where they are promised good health, prosperity, marriages and travelling opportunities to the UK or America.

Material blessings (fertility and children, good health, secure shelter, plentiful harvests) are explained as signs of divine blessing. Conversely, all the problems occurring in life are seen as having spiritual provenance. In other words, the root of all problems is spiritual and, therefore, the solution must also be spiritual. It implies that every individual is responsible for his or her success in life. If one cannot overcome by oneself the forces that hinder success, one has to look for assistance from those who have the power needed to summon or manipulate spiritual forces. In response to the general social and political situation in a continent that is characterised by challenges of poverty, disease, civil war, unemployment, the need to find marriage partners, barrenness and, generally, the lack of responsible government, many people turn to Pentecostal-charismatic churches, looking for help. It is now 
becoming common practice to visit so-called 'prophets' who feature on satellite television and in social media as being able to meet various needs in peoples' lives. In addition, as a result of contemporary migration from the global south to the global north, African forms of Christianity are 'exported' to Europe and America. Hence the number of migrant churches in Europe is increasing (Jenkins 2007: 192).

In Africa, particularly in sub-Saharan Africa, the expansion of Pentecostal-charismatic churches has impacted on mission churches. The strong desire of people to see their sociopolitical environment and their economic position improve, makes them turn to the Pentecostals and many mission churches have lost members. Sometimes mission churches find that their members belong to Pentecostal-charismatic churches as well because they crave the performance of miracles that promise a response to their social and economic needs (cf. Kalu 2008). To stop members from joining Pentecostal-charismatic churches or from having dual church membership, mission churches have allowed their congregations to indulge in expressions of worship that are more commonly found in Pentecostal-charismatic churches (UCZ Synod 2013:90-91). These include speaking in tongues and using holy water and anointing oil when performing healing sessions. Some forms of worship include the use of blessed clothes, perceived as having healing powers, and accentuating the possibility of attaining material blessings such as being married and getting a car, a job, or a visa for the USA or the UK (cf. Anderson 1992; Kalu 2002, 2008).

Undoubtedly, the featuring of prophecy and miracles plays a prominent role in the growth of Pentecostal-charismatic churches (Amanze 2013; Anderson 1992; Kalu 2002, 2008). Amanze (2013) succinctly captures this phenomenon:

The church in Africa is growing in leaps and bounds unprecedented in the history of Christianity since its introduction on the continent in the 19th century. This growth and development, however, is taking place mainly in the New Religious Movements, particularly the Pentecostal-charismatic churches because of their emphasis on the prophetic ministry characterised by performance of healing miracles and predicting the future. (p. 1)

The phenomenon of prophecy whereby predictions are thought to be fulfilled inspires the faithful with a trust that the prophet or prophetess concerned is indeed a person of God. Amanze (2013:9) argues that prophecy and healing contribute to the success of TB Joshua and the growth of the Synagogue Church of All Nations in Nigeria (SCOAN). Amanze (2013:10) states that TB Joshua's healing miracles and prophecies which appear to be accurate 'seem to attract many people to SCOAN who strongly believe that Joshua has supernatural powers bestowed upon him by God'.

The author of the present article concurs with Amanze (2013) but adds that, inherent in the prophecies and related activities that attract people to SCOAN and to many other Pentecostal-charismatic churches in Africa, is the principle of retribution.

\section{Prophecy}

Amanze (2013) has convincingly shown that prophecy and healing have contributed to the growth of prophet TB Joshua's ministry and his SCOAN that draws people, not only from Nigeria, but also from, inter alia, South Africa, Zambia, Malawi, Zimbabwe, Ghana, Cameroon, and Gambia. In the past two decades, many African leaders have visited SCOAN, seeking miracles and blessings. According to Amanze (2013), they include the former governor general of the republic of the Bahamas, the late president of Ghana, John Atta Mills, and Frederick Chiluba, former president of Zambia who visited SCOAN in 2000. SCOAN has furthermore been visited by Zulu king Goodwill Zwelithini (who has recently been accused of fuelling xenophobic attacks in South Africa), president Omar Bongo of Gabon, former president of Malawi Joyce Banda, former Zimbabwean prime minister Morgan Tsvangirai, Winnie Madikizela-Mandela and Julius Malema who reportedly visited TB Joshua in August 2013 for spiritual blessings (Amanze 2013:5-9; Emmanuel TV 11 January 2009; Njoku 2015).

These visits by African leaders have inspired many Africans to follow their example and make a pilgrimage to Nigeria in search of prophecy and healing miracles (Amanze 2013:5, 8, 9). Hence, when in September 2014 a SCOAN hostel owned by Joshua collapsed there were no less than 84 South Africans among the victims. They had gone to SCOAN expecting miracles and healing but were overtaken by fate (Njoku 2015). A close look at the ministry of TB Joshua as shown on his live Sunday services on Emmanuel TV and at SCOAN website information teaches us that, clearly, thousands of people are attracted to this church by prophetic messages, healing and messages referring to material success that are reinforced by a theology of retribution.

According to Amanze (2013) TB Joshua does predict events that indeed come to pass. Emmanuel TV broadcasts occurrences that - it claims - have been foretold by TB Joshua. It has recently emerged that TB Joshua may have predicted the xenophobic attacks in South Africa. A video surfaced of TB Joshua warning South Africa for a 'youth revolt' in their nation that would result in the death of 'certain people'. On the video, broadcast by Emmanuel TV, Joshua is seen as he on 28 July 2013 - states:

In the nation South Africa, we should help them in prayer because I am seeing youth revolt. It will be very serious. A situation where youth will come out and ... you learn that there is a protest. Some people were killed - certain people. (Njoku 2015; Emmanuel TV, 28 July 2013)

Interestingly, TB Joshua's prediction of xenophobic attacks in South Africa is broadcast by Emmanuel TV together with a prayer for South Africa that seems to have been offered by Julius Malema when he visited SCOAN in August 2013:

If we fail to see that there are powers that cause people to be bowed down in bondage, we are going to fight the wrong battle ... I pray for my nation, South Africa. As Jesus stood in the boat 
and commanded the storms to be calm, I stand in the midst of the storm in my nation, South Africa and I command the storm, wind and waves to be calm, in the name of Jesus! I speak calmness to my nation, South Africa, in the name of Jesus! (Njoku 2015; eNCA, 13 August 2013)

His predictions have made of TB Joshua arguably the most popular pastor in Africa. The theology of retribution is evident also in the prayer for South Africa, and strongly appeals to visitors of SCOAN. TB Joshua usually links the problems of his visitors to their sinful lives. He begins by finding out for what specific problem they need his help. He then links it to some sinful deed in a person's past or present and asks him or her to repent. After receiving the miracle of healing, the client promises to follow Jesus and not to sin anymore. Clients normally shout: 'Man of God, I will sin no more'. The phenomenon of prediction and fulfilment, coupled with a belief that every good act attracts blessings and every bad deed gets punished, makes SCOAN attractive to many Christians. According to Amanze it cannot be denied that prophet TB Joshua's predictions come true and that often his knowledge of things that have happened in secret turns out to be correct (Amanze 2013:5,10).

The principle of retribution appears to be supported by the traditional African belief that someone is always responsible for the negative events in one's life. Calamities are sent by offended ancestors or by human beings who practice witchcraft aiming to cause one pain (Kalu 2008:186). During a national day of prayers, fasting and reconciliation, organised by the Zambian government on 18 October 2015, Bishop Peter Ndhlovu, overseer of the Bible Gospel Church in Africa (BIGOCA) and apostle, declared:

Elijah called upon you and fire came from heaven. Do to us what you did to Elijah. May you bring fire to destroy all satanic altars. This nation will prosper. The economy will boom. Mines will be discovered. We confess the sins of our forefathers; for they worshiped idols. The economy of Zambia will be the best in Africa. (Lusaka Times, 18 October 2015)

The prayers were organised to ask for divine intervention in Zambia's economy, which has been worsening due to the declining price of copper at the London Metal Exchange. According to the bishops of most Pentecostal-charismatic churches in Zambia, the poor economy of Zambia is the result of disobedience to God's commandments. Through confession and by the destruction of all satanic altars the economy of Zambia could improve. This view is confirmed by Bishop Joe Imakando of the Bread of Life Church International in Lusaka who is also the chairperson of the Evangelical Fellowship of Zambia, an umbrella body that unites the Zambian Pentecostal and Evangelical churches. The bishop urged Zambians to pray for the improvement of the economy:

The depreciation of the kwacha against the dollar has resulted in prices escalating by 30 percent to 100 percent. Efforts by government to reverse the situation have not yielded any fruit. The impending increase on fuel will cause yet another price escalation, which will further complicate matters. What we need is divine intervention! (Hill 2015; Imakando 2015)
As Kalu (2008:186) notes, Pentecostal-charismatic churches in Africa have produced a culture of continuity by retrieving aspects of primal worldviews. They exhibit a pneumatic and charismatic religiosity that existed in traditional society. Also, in the African worldview, it is one's own misdeeds that may be the cause of troubles. Therefore, to discover the source of a problem, Africans seek the help of the diviner. He or she detects the root cause of the trouble by manipulating vital forces (spiritual powers). The sufferer is responsible for his or her destiny and has to repent of, and to renounce, bad deeds done by him or her, or committed by his or her ancestors during their lifetime. By summoning the vital forces, the prophet or prophetess breaks generational curses and omens on behalf of the client.

Anderson (2000:8) observes that African Pentecostalcharismatic churches provide 'a setting in which the African conviction that spirituality and healing belong together is dramatically enacted'. In the African worldview, rituals for healing and protection against evil powers are prominent. During his term as president of Zambia, Frederick Chiluba visited SCOAN (Emmanuel TV, 30 August 2009). When attending a church service he stated:

Kings that depended on God guided their nations easily and successfully. God never changes yesterday, today and forever. If we depend on God we will not be worse than those kings [who] depended on God before. We will do extremely well. (Emmanuel TV, 15 January 2013)

Frederick Chiluba and many other followers of TB Joshua, including presidents and leaders whose rule has run into trouble, believe that they have committed some sin or are the victims of a generational curse (cf. 2 Chr 26:16-19). Blessings and curses in the book of Deuteronomy are read in the light of physical and material success in Jesus Christ. It is believed that God, through Jesus Christ, has made a new covenant which includes blessings and curses. Those who believe in Jesus and God's commandments will enjoy protection, success and material blessings on earth. Chris Kwakpovwe (2014), a pastor in Nigeria, who is also a publisher of the Daily Manna, declares:

You cannot hear from God and be a failure on this planet! Hearing from God is the secret of the great! That is my main open secret! I do not ever take any step without hearing from God. The few times I was not patient to hear him properly, I suffered greatly for it. (n.p.)

Preaching a sermon from John 1:12 on 4 October 2015 in Pretoria, South Africa, prophet Shepherd Bushiri ${ }^{10}$ declared: 'It is your problem if you do not have influence in life. It is not the problem of Jesus. Those who believed in Jesus he gave them power to influence things'. He went on to declare that all people in the Bible, from Moses, Solomon and David to Jesus, Peter and Paul, were rich and successful. He challenged the congregants to become rich and successful by

10................................................................................... Church in Pretoria, South Africa. According to Nyasa Times, the church has over ten thousand registered members who attend Sunday services that are also broadcast thousand registered members who attend Sunday services that are also broadcast
live on Prophetic Channel, accessed on Digital Satellite Television and free for air decoders (Nyasa Times, 26 May 2015) 
obeying God's commandments and sowing a seed of blessings through offerings. Such challenges would explain why political and traditional leaders in sub-Saharan Africa flock to prophets in Pentecostal-charismatic churches to obtain blessings (Emmanuel TV 15 January 2013; eNCA, 13 August 2013). Bad leaders are compared to king Azariah (Uzziah) of Judah who was struck by Yahweh with leprosy (2 Chr 26:16-19).

\section{Healing}

Prophecy is usually accompanied by healing miracles. Many prophecies and cases of healing are based on the principle of retribution which, as noted above, is rooted in the African worldview that there is always a specific being or thing responsible for one's failures in life. A man with a swollen scrotum due to cancer visited SCOAN and after prayers by TB Joshua the scrotum burst and eventually healed (Emmanuel TV, 31 October 2012). Joshua linked the illness to the man's sinful past. Thus, the man, after being healed, promised to follow Jesus and not sin anymore. A married couple from the USA came to SCOAN seeking miracles. TB Joshua admonished the man for thinking that he could marry any woman, simply because he had money. Joshua told the woman that she had married a spirit. According to TB Joshua the spiritual husband destroyed both their marriage and the business that the man had been running before they got married (Emmanuel TV, 25 December 2012). In other words, the couple itself was responsible for their marital problems and needed to repent of their sins. After prayer by TB Joshua, the marriage was miraculously restored.

It is believed that by defining blessings and curses, God brings to completion acts that have been set into motion by human beings. Hence, human beings should take responsibility for unfortunate occurrences in their lives rather than blaming God (cf. Forti 2014:140; Koch 1983: 59-61). Kwakpovwe (2010) urges:

Be a self-starter! Let your first hour each day set the theme of success and positive action that is certain to echo through your day. Today will never happen again. Don't waste it with false start or no start at all. You were not born to fail ... Ask the blood of Jesus to wash you from any known or unknown sin [...]. (p. 7)

Similarly, David O. Oyedepo of the Living Faith Church Worldwide (aka Winners Chapel) in Nigeria on 16 February 2016 declared:

When God's Word is put to work, the powers of darkness are shattered. Let's recognize that the dominion of light over darkness is instant and unquestionable. For instance, when we turn on the light in a room, darkness gives way instantly.... Every Word received, believed and engaged becomes as unstoppable as God. Remember, from the story of creation, we understand that the earth was without form and void but at the instance of God's Word, it took shape and colour [...]. (Oyedepo 2016)

There are many different kinds of Pentecostal-charismatic churches in Africa. While some do not preach about sin and its consequences for one's life on earth (Anderson 2000:8; Togarasei 2015:63-64), others do. As shown in this article, the prophets TB Joshua, Shepherd Bushiri and others tend to link the problems of their clients to a sinful past or to generational curses in the family (Emmanuel TV 2015, Prophetic Channel; 12 August 2015). As Anderson (2000:8) observes, Pentecostalcharismatic churches in Africa respond to what they experience as a void left by a western form of Christianity that has destroyed African cultural and spiritual values. African Pentecostal-charismatic churches reclaim ancient Biblical traditions of healing and protection from evil and demonstrate the practical effects of these traditions. Thus, Pentecostal-charismatic churches make a significant contribution towards meeting the physical, emotional and spiritual needs of African people. During a miracle conference at Wanderers Stadium in Johannesburg (28-30 August 2015), many people claimed they had received miracles of healing and material success after prophet Uebert Angel Mudzanire ${ }^{11}$ of Spirit Embassy in Zimbabwe prayed for them. One woman said that she had received a text message inviting her to be interviewed for a job that she had never applied for (Shepherd Bushiri Ministries, 30 August 2015). Preaching in Pretoria in South Africa during a miracle conference from 09 to 12 October 2015, Prophet Jeremiah Omoto Fufeyin, founder of Christ Mercy Land Deliverance Ministry in Nigeria, testified of his material success as follows. 'Call any latest car, I have it. I have not bought it with my money. Rather I have been given it by people I have blessed'. He challenged the congregants to obey God's commandments so that they would receive material blessings on earth, here and now (Prophetic Channel, 11 October 2015; cf. Vanguard News, 31 May 2016).

It is evident that the success of prophets and pastors in many Pentecostal-charismatic churches is based on an ability to select certain elements from the Bible that appeal to African people and give them hope that their spiritual, social, economic and political needs will be fulfilled (cf. Amanze 2013). Most of these Biblical elements re-enforce the principle of retribution.

Although not homogeneous, Pentecostal-charismatic churches in Africa generally offer a pragmatic Christian ministry that seeks to address practical needs such as ill health, poverty, unemployment, loneliness, fear of evil spirits and sorcery (Anderson 2000:14). In their many varied forms, and due to their inherent flexibility and sympathetic approach to both African and Western worldviews, African Pentecostal-charismatic churches offer answers to some of the fundamental questions asked in their specific context (Anderson 2000:14). Unlike mainline churches that position the consequences of one's sins in a future existence in heaven or hell, the Pentecostals believe that such consequences occur on earth. Hence they promise material blessings for those who obey God. The concept of fear of

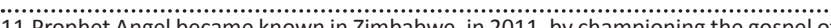
prosperity. He quickly became one of the most sought after prophets locally and prosperity. He quickly became one of the most sought after prophets locally and
regionally. Fondly referred to as 'Papa' by church members at Spirit Embassy, the
prophet is known for his collection of flashy cars and a free to air satellite TV prophet is known for his collection of flashy cars and a free to air satellite TV Channel called Miracle TV (The Standard, 01 March 2015). 
God is reformulated in terms of rewards that may take the form of wealth, honour and long life (cf. Forti 2014:132, Prov 23:17-18).

Clearly, it is difficult to prove that the ideal of retribution administered by a just and omnipotent God is a reality, especially considering the amount of suffering in the world, particularly Africa. The notion that punishment and suffering are consequences of evil actions is supported by evidence from daily life. But a problem arises when the statement is reversed and a person's misery is interpreted as an indication that he or she has committed a sin (Wittenberg 1994:63). Misfortune is not always the logical and inevitable consequence of evil deeds. Some people fall victim to evil and corrupt social structures (cf. Wittenberg 1994:63). Therefore, the connection between sin and impoverishment on the one hand and obedience to God's Word and material success on the other requires further analysis. At the same time it seems certain that, whether it is presented as prosperity gospel or as health and welfare theology, the concept of retribution is an integral part of the messages preached in African Pentecostal-charismatic churches (cf. Gifford 1991:10; Okyerefo 2016).

\section{Conclusion}

This article examines factors that have led to the tremendous growth of Pentecostal-charismatic churches in Africa. It discusses the shifting of the centre of gravity of world Christianity to the global south and it defines the important role played in this development by the different types of Pentecostal-charismatic churches in Africa. The article engages furthermore with the central position of the theology of retribution in prophecies and healing sessions of African Pentecostal-charismatic churches. It argues that an important part of the appeal of prophets and pastors in Pentecostalcharismatic churches in Africa lies in their use of the theology of retribution. The commandments of God are seen as relevant to both religious-ethical and didactic-pragmatic frameworks. They appeal to the human conscience, holding out the promise of rewards for those who act with moral justification (Forti 2014:137). Believing in a natural law whose power derives from a belief in divine providence, Pentecostal-charismatic churches in Africa link the consequences for bad actions to divine retribution (cf. Forti 2014:140; Licht 1982). Through their performance of prophecy and healing miracles that are reinforced by the principle of retribution Pentecostal-charismatic churches in Africa are well-positioned to respond to the spiritual, social, economic and political needs of African people. This has contributed considerably to the fast growth of Christianity in Africa south of the Sahara.

\section{Acknowledgements Competing interests}

The author declares that he has no financial or personal relationships which may have inappropriately influenced him in writing this article.

\section{References}

Adedibu, B., 2015, 'Mission from Africa: A call to re-imagine mission in African-led Pentecostal churches in Britain', Missio Africanus: Journal of African Missiology $1(1), 39-52$.

Amanze, J.N., 2013, 'The role of prophecy in the growth and expansion of the Synagogue Church of All Nations', Scriptura 112(1), 1-14.

Anderson, A., 1992, Bazalwane: African Pentecostals in South Africa, University of South Africa, Pretoria.

Anderson, A., 2000, Evangelism and the growth of Pentecostalism in Africa, University of Birmingham, Centre for Missiology and World Christianity, UK, viewed 18 September 2015, from http://artsweb.bham.ac.uk/aanderson/Publications/ September 2015, from http://a
evangelismandthegrowthofpe.htm

Anderson, A., 2004, An introduction to Pentecostalism and Global Charismatic Christianity, Cambridge University Press, Cambridge.

Anderson, A., Bergunder, M., Droogers, A. \& Van der Laan, C (eds.), 2010, Studying global Pentecostalism: Theories and methods, University of California Press, Los Angeles, CA.

Barrett, D., Kurian, G. \& Johnson, T., 2001, World Christian encyclopedia, 2nd edn., Oxford University Press, New York.

Beecher, M., 2015, History of opinions on the scriptural doctrine of retribution, viewed 15 March 2016, from http://www.tentmaker.org

Bosman, H., 2014, 'From "Divination" to "Revelation"? A post exilic theological perspective on the relationship between law and prophets in the Old Testament', perspective on the re
OTE 27(2), 377-394.

Emmanuel TV, SCOAN live Sunday service (in Zambia), viewed 06 September 2015, from http://emmanuel.tv/

Emmanuel TV, 2013, T. B. Joshua's prophecy about xenophobic violence in South Africa, 28 July, viewed 15 March 2015, from https://www.youtube.com/ watch?v=ZKNC6qERgsw

Emmanuel TV, 2013, President of Zambia Frederick Chiluba visits T B Joshua, 15 January, viewed 02 May 2015, from https://www.youtube.com/watch?v=225ZU8Rh6E

Emmanuel TV, 2012, Deliverance of a man with cancer, 31 October, viewed 03 March 2015, from https://www.youtube.com/watch?v=TqxvMiX9yFU

Emmanuel TV, 2012, Deliverance of a couple from USA, 25 December, viewed 03 May 2015, from https://www.youtube.com/watch?v=Sd1HBASxQg|

Emmanuel TV, 2009, Ghana President Atta Mills visits T. B. Joshua, 11 January, viewed 11 March 2015, from https://www.youtube.com/watch?v=VifKmCFBXac

Emmanuel TV, 2009, Former Zambia Frederick Chiluba, 30 August, viewed 04 May 2015 from https://www.youtube.com/watch?v=a6n7904Lvx4

eNCA News, 2013, Malema heads to Nigeria for blessings, 13 August, viewed 19 April 2015, from https://www.youtube.com/watch?v=xwbryg7YdJQ

Forti, T., 2014, 'The concept of "reward" in proverbs: A diachronic or synchronic approach?', Currents in Biblical Research 12(2), 129-145. http://dx.doi.org/ approach?', Currents in Biblica
$10.1177 / 1476993 \times 12459635$

Gifford, P., 1991, 'Christian fundamentalism and development in Africa', Review of African Political Economy 19(52), 9-20. http://dx.doi.org/10.1080/ 03056249108703918

Gifford, P., 1998, African Christianity: Its public role, Indiana University Press, Bloomington, IL.

Hazra, K., 2003, Background to Pentecostalism and the Charismatic movement, United Church of Zambia Theological College training manual, Kitwe, Zambia.

Hill, M., 2015, Zambia's president seeks divine intervention in a declining economy, Bloomberg 16 October 2015, viewed 25 October 2015, from http://www. chicagotribune.com/news/sns-wp-blm-zambia-6074ee4a-7414-11e5-ba14318f8e87a2fc-20151016-story.htm

Imakando, J., 2015, National day of prayer, fasting and reconciliation, viewed 25 October 2015, from http://www.blci.info/index.php/news/item/264-nationalday-of-prayer-fasting-and-reconciliation

Jenkins, P., 2007, The Next Christendom: The coming of global Christianity, Oxford University Press, Oxford.

Johnson, T. \& Ross, K., 2009, Atlas of global Christianity: 1910-2010, Edinburgh University Press, Edinburgh.

Kalu, O., 2008, African Pentecostalism: An introduction, Oxford University Press, Oxford.

Kalu, O.U., 2002, 'Preserving a worldview: Pentecostalism on the African maps of the universe', Pneuma 24(1), 110-137. http://dx.doi.org/10.1163/ 15700740260388009

Koch, K., 1983, 'Is there a doctrine of retribution in the Old Testament?', in J.L. Crenshaw (ed.), Theodicy in the Old Testament, pp. 57-87, Fortress Press, Philadelphia, PA.

Kwakpovwe, C.E., 2010, Our daily manna: A devotional booklet for champions, Our Daily Manna, Lagos.

Kwakpovwe, C.E., 2014, Uncommon secrets of hearing God's voice in all situations, Our Daily Manna, Lagos.

Lado, L., 2006, 'African Catholicism in the face of Pentecostalism', in E.M. Metogo (ed.), African Christianities, pp. 22-30, SCM Press, London.

Licht, L., 1982, 'Reward and punishment', in B. Mazar et al. (eds.), Encyclopaedia biblica, p. 292, Bialik Institute, Jerusalem. 
Lusaka Times, 2015, President Lungu declares October 18th a public day of prayers, 18 October, viewed 18 October 2015, from https://www.lusakatimes.com/2015/ 10/18/president-lungu-declares-october-18th-a-public-day-of-prayers/

Mayor, M., Engineer S., Handorf S., O'Shea S., Stern K., Williams J. et al. (eds.), 2002, Macmillan English dictionary for advanced learners, Macmillan, London, s.v., 369.

Mbiti, J., 1974, 'Some reflections on African experience of salvation today', in S.J. Samartha (ed.), Living faiths and ultimate goals: A continuing dialogue, pp. 108119, WCC Publications, Geneva.

McConville, G., 1994, 'Deuteronomy', in D.A. Carson et al. (eds.), New Bible commentary, 4th edn., pp. 198-232, IVP, Leicester.

Menezes, R., 2013, Wisdom traditions of Israel, St. Paul Press, Mumbai.

Njoku, I., 2015, I predicted South Africa's xenophobic attacks - T B Joshua. Premium Times, 17 April, viewed 15 March 2015, from http://www.premiumtimesng.com/ news/top-news/181588-i-predicted-south-africas-xenophobic-attacks-tb-joshua. html

Nyamiti, C., 1987, 'The doctrine of God', in J. Parrat (ed.), A reader in African Christian theology, pp. 58-68, SPCK, London.

Nyasa Times, 2015, Prophet Bushiri takes South Africa by storm - Church growing alarmingly, 26 May, viewed 31 August 2015, from http://www.nyasatimes. com/2015/05/26/prophet-bushiri-takes-south-africa-by-storm-church-growingalarmingly/

Okyerefo, K.M.P., 2016, The Gospel of public image in Ghana, ClHA blog, viewed 01 March 2016, from http://www.cihablog.com/the-gospel-of-public-image-inghana/

Oyedepo, D.O., 2016, Engaging the Breakthrough Power of the Word! Faith Tabernacle, 14 February, viewed 21 February 2016, from http://faithtabernacle. org.ng/sermon/signs-wonders-sunday-february-14-2016/

Phiri, I.A., 2008, 'President Frederick Chiluba and Zambia: Evangelicals and democracy in a "Christian Nation"', in O.R. Terence (ed.), Evangelical Christianity and democracy in Africa, pp. 95-249, Oxford University Press, Oxford.

Pobee, J., 1996, West Africa: Christ would be an African too, WCC, Geneva.

Prophetic Channel, 2015, Live Sunday service, 11 October, viewed from free to air satellite Television in Zambia, http://propheticchannel.info/
Prophetic Channel, 2015, Why some get healed while others not, 12 August, viewed 01 March 2016, from http://propheticchannel.info/

Robert, D.L., 2000, 'Shifting Southward: Global Christianity since 1945', International Bulletin of Missionary Research 24(2), 50-58. http://dx.doi.org/10.1177/ 239693930002400201

Robert, D.L., 2009, Christian mission: How Christianity became a world religion, Willey-Blackwell, Chichester.

Sanneh, L., 1990, 'The changing face of Christianity: The cultural impetus of a World Religion', in L. Sanneh \& J. Carpenter (eds.), The Changing face of Christianity: Africa, the West and the World, pp. 159-190, Oxford University Press, New York.

Sanneh, L., 2008, Disciples of all nations: Pillars of World Christianity, Oxford University Press, Oxford.

Schreiter, R.J., 2004, The new Catholicity: Theology between the global and the local, Orbis Books, MaryKnoll, NY.

Schreiter, R.J., 1991, Faces of Jesus in Africa, Orbis Books, Maryknoll, NY.

Shepherd Bushiri Ministries, 2015, Encounter Conference Update, 30 August, viewed 31 August 2015, from https://www.facebook.com/shepherdbushiriministries

The Standard, 2015, Uebert Angel - From Grace to Grass, 01 March, viewed 31 August 2015, from http://allafrica.com/stories/201503010267.htm

Togarasei, L., 2015, 'Modern/charismatic Pentecostalism as a form of "religious" secularization in Africa', Studia Historiae Ecclesiasticae 41(1), 56-66.

UCZ Synod, 2013, Minutes of the Synod executive meeting of the United Church of Zambia held from 3-4th November, Synod Publications, Kabwe.

Vanguard News, 2015, I am not Junior TB Joshua -Fufeyin of MercyLand, 31 May viewed 13 February 2016, from http://www.vanguardngr.com/2015/05/i-am-notjunior-tb-joshua-fufeyin-of-mercyland/

Walls, A.F., 2002, The cross-cultural process in Christian history, Orbis Books, Maryknoll, NY.

Wittenberg, G., 1994, 'Counselling aids patients: Job as a paradigm', Journal of Theology for Southern Africa 88, 61-68.

Wittenberg, G., 2007, Resistance theology in the Old Testament: Collected essays, Cluster Publications, Pietermaritzburg. 